\title{
Accumulation of an earthquake-induced extremely turbid layer in a terminal basin of the Nankai accretionary prism
}

\author{
Juichiro Ashi ${ }^{*}$, Ritsuko Sawada ${ }^{2}$, Akiko Omura ${ }^{3}$ and Ken Ikehara ${ }^{4}$
}

\begin{abstract}
Seismic shaking is a major trigger for sediment redistribution in subduction zones, and clouds of dilute suspended sediment have been reported in association with large earthquakes. Dive observations in a basin on the slope of the central Nankai accretionary prism soon after the 2004 off-Kii Peninsula earthquakes documented a layer of suspended sediment with extremely high turbidity. We estimated the thickness of this bottom turbid layer to be more than $2.5 \mathrm{~m}$ by comparison of seafloor depths between surveys in 2004 and 2010 and about $2.6 \mathrm{~m}$ from instrumental evidence involving the submersion of a heat-flow probe. A high-resolution subbottom profiling survey across the basin revealed acoustically transparent layers thicker than $2 \mathrm{~m}$. Because the slope basin is a terminal basin completely enclosed by topographic highs, we examined the possibility that the uppermost transparent layer was deposited as a consequence of the 2004 earthquakes. Considering the sediment source area and the volume of the basin fills, the mobilization and redeposition of thin surface sediments on the prism slope can account for the volume of the transparent layer. We conclude that the 2004 earthquakes caused widespread disturbance of the prism slope and concentrated surface sediments in this terminal basin. Our results emphasize the utility of a terminal basin in a subduction zone as an earthquake recorder.
\end{abstract}

Keywords: Suspension cloud; Terminal basin; Slump; Sliding; Gravity flow

\section{Findings \\ Introduction}

Sedimentary processes in subduction zones are basically controlled by geomorphological evolution in response to short-term events related to the tectonic formation of sedimentary basins, deep-sea canyons, or steep scarps, as well as long-term sea-level changes and hinterland tectonics. Short-term sedimentation processes include various events that accompany earthquakes and volcanic activities. Subduction earthquakes, in particular, mobilize and redeposit a considerable amount of sediment as a result of slope instability and tsunamis (e.g., Seeber et al. 2007; Noguchi et al. 2012; Arai et al. 2013). Sedimentary processes associated with earthquakes are crucial to the understanding of sedimentation systems in a subduction

\footnotetext{
* Correspondence: ashi@aori.u-tokyo.ac.jp

${ }^{1}$ Atmosphere and Ocean Research Institute, The University of Tokyo, 5-1-5

Kashiwanoha, Kashiwa, Chiba 277-8564, Japan

Full list of author information is available at the end of the article
}

zone. Moreover, paleoseismic histories that can be deduced from sedimentary records and the assessment of tsunami hazards associated with submarine slope failures provide important information for disaster mitigation (e.g., Goldfinger 2011; Yamada et al. 2012).

Submarine slope failures induced by seismic shaking have been investigated by seismic reflection surveys, swath bathymetry, and sediment sampling (e.g., Sultan et al. 2009; Goldfinger 2011). Autobrecciation of unconsolidated surface sediment, which is considered to represent evidence of seafloor deformation by earthquake shaking as well as sliding or slumping, was reported from the source areas of the 1993 earthquake off southwestern Hokkaido (Takeuchi et al. 1998) and the 2004 Sumatra earthquake (Seeber et al. 2007). Tsunamis were reported as an important agent of sediment redistribution from the $365 \mathrm{AD}$ Cretan earthquake (Polonia et al. 2013) and the 2011 Tohoku earthquake (Noguchi et al. 2012; Arai et al. 2013; Ikehara et al. 2014). The wellknown sequential breakage of undersea communication 
cables after the 1929 Grand Banks earthquake was the first documentation of landslide-triggered turbidity currents (Heezen et al. 1954). Suspended sediments in the water column after large earthquakes were reported by (1) in situ monitoring of light scattering and sediment traps from the Cariaco basin (Thunell et al. 1999), (2) sediment traps from the epicentral region of the 1994 Sanriku earthquake (Itou et al. 2000), (3) dive observations in the weeks after the 2004 Sumatra earthquake (Seeber et al. 2007), and (4) strong turbidity anomalies above the seafloor from turbidity sensor monitoring 1 month after the 2011 Tohoku-oki earthquake (Noguchi et al. 2012). The deep seafloor observatory in the Sagami Trough off Japan monitored mudflows caused by a moderate earthquake in real time (Kasaya et al. 2009).

Suspended sediment clouds have also been recognized after the 2004 off-Kii Peninsula earthquakes (maximum magnitude 7.4) in the Nankai subduction zone (Ashi et al. 2012). Such a layer of extremely high turbidity was observed in a basin on the prism slope. This layer is apparently similar to lutoclines observed between heavily mud-laden bottom layers and clearer overlying layers in estuaries and muddy coastal environments (e.g., Wolanski et al. 1988). This study reports details of the observation of a bottom turbid layer in the slope basin off Kii Peninsula, documents sedimentary structures from a subbottom profiling survey, and discusses the source and redeposition processes associated with the high-turbidity layer.

\section{Geological and geophysical background}

The Nankai Trough is a convergent margin more than 700-km long where the Philippine Sea Plate subducts to the northwest beneath the Eurasian Plate at 4.1 to $6.5 \mathrm{~cm} /$ year (Seno et al. 1993; Miyazaki and Heki 2001). Accretionary prisms are well developed along the Nankai Trough. The central Nankai Trough region, including the study area, is characterized by NE-SW-trending continuous outer ridges and elongated depressions separating the prism slope from the Kumano forearc basin (Figure 1). These features cut off direct drainage paths from the forearc basin to the Nankai Trough. Multichannel seismic reflection data have shown that a megasplay fault branching from the master décollement formed these outer ridges (e.g., Park et al. 2002; Moore et al. 2007). The depressions are interpreted to have been formed by the strike-slip component of oblique subduction (Ashi et al. 2007; Martin et al. 2010). To better understand the seismogenic zone, the Nankai Trough Seismogenic Zone Experiment (NanTroSEIZE) of the Integrated Ocean Drilling Program (IODP) targeted this mega-splay fault (e.g., Tobin and Kinoshita 2006; Kinoshita et al. 2009). Mud-breccia units were observed in the drilled cores from the hanging wall of the

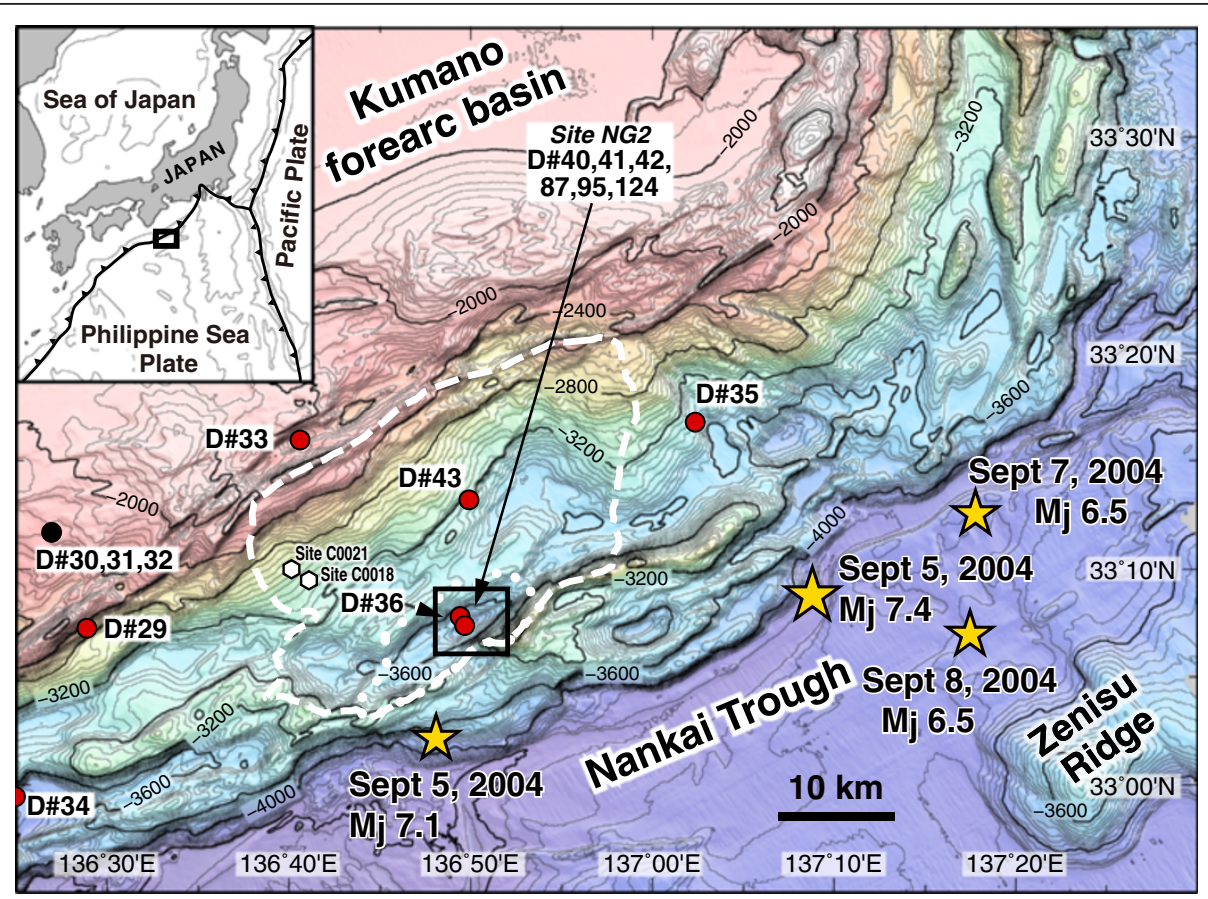

Figure $\mathbf{1}$ Bathymetric map of the central Nankai subduction zone; contour interval is $\mathbf{4 0} \mathbf{m}$. Yellow stars show epicenters of the 2004 off-Kii Peninsula earthquakes, and the epicenters and magnitudes were estimated by the Japan Meteorological Agency. Circles show locations of dive sites with (red) and without (black) a dilute suspension layer. White dotted and dashed lines outline the estimated sediment source area to the basin (see text for more explanation). Rectangle corresponds to the area covered by Figure 2. Hexagons are IODP drilling sites. 
mega-splay fault, and the shallowest of these was attributed to strong ground shaking during the 1944 Tonankai earthquake (Sakaguchi et al. 2011).

Historical and archeological records have documented recurring great earthquakes along the Nankai Trough (Ando 1975). However, few medium-sized or large earthquakes have been recorded during the period between great earthquakes. The 2004 off-Kii Peninsula earthquakes in September 2004 were a series of large events near the axis of the Nankai Trough. The epicenter of the September 5 mainshock (Japan Meteorological Agency magnitude $\mathrm{Mj}=7.4$ ) was northwest of Zenisu Ridge (Figure 1). About $5 \mathrm{~h}$ before the mainshock, there was a foreshock (Mj 7.1) about $40 \mathrm{~km}$ to the southwest. Small tsunamis were recorded after both of these earthquakes. Major aftershocks (Mj 6.5) occurred $20 \mathrm{~km}$ east of the mainshock on September 7 and 8. The aftershock distribution was mapped as extending in both the NW-SE and the ENE-WSW directions by ocean bottom seismometers (Sakai et al. 2005). The four shocks were interpreted as intraplate earthquakes in the subducting Philippine Sea Plate. Tsunami waveform inversion results suggested that the fault strike of the mainshock was perpendicular to the trough axis and that the foreshock was caused by dip-slip on an ENE-WSW-striking fault (e.g., Saito et al. 2010).

The study area is on the accretionary prism slope and is characterized by ridge-and-trough structures (Figure 1). A detailed survey was conducted 6 and 7 years after the earthquakes in the NE-SW elongated slope basin (see location rectangle in Figure 1) where an extremely turbid layer was observed at the seafloor (Ashi et al. 2012). This slope basin is a terminal basin that is completely enclosed by topographic highs (Figure 2). IODP Expeditions 333 and 338, as part of the NanTroSLIDE (Nankai Trough Submarine Landslide History) project for investigating landslide processes in an accretionary prism margin (Strasser et al. 2012; Moore et al. 2014), drilled two sites $20 \mathrm{~km}$ upslope from the terminal basin (sites C0018 and C0021 in Figure 1). However, the targets
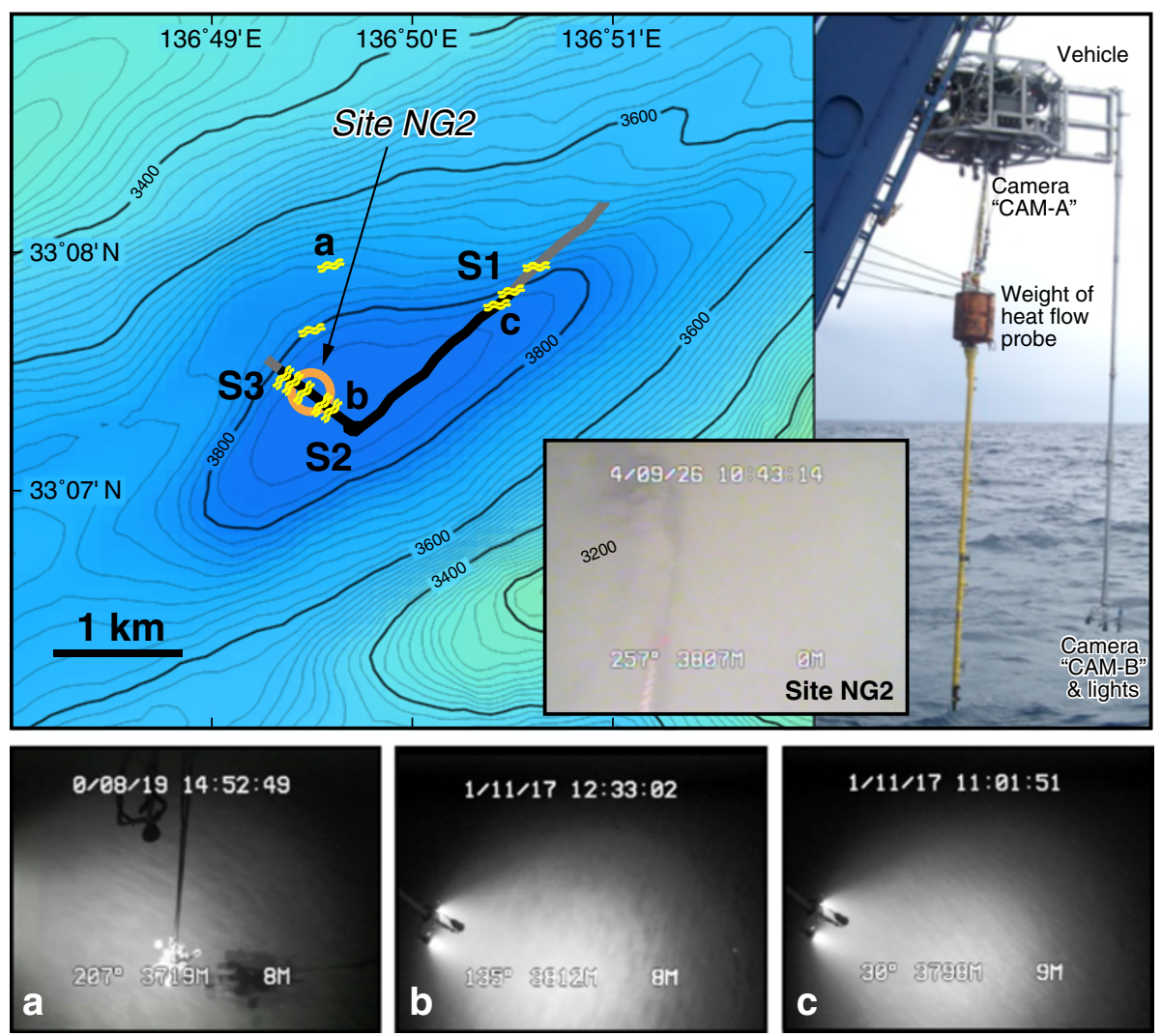

Figure 2 Bathymetric map, heat-flow probe system, CAM-B image, and video images of ripple-like bedforms. Bathymetric map (upper left) of the terminal basin in the prism slope; contour interval is $20 \mathrm{~m}$ (see Figure 1 for location). Yellow wavy lines show the crest directions of ripple-like structures. Thick line indicates the route of the subbottom profiling survey of dive 124. The black portion of the profile line, from S1 to S3, is shown in Figure 7. An orange circle denotes the site NG2 surveyed during the dives 40,41,42, and 87. The upper right photo shows the heat-flow probe system suspended from the pilot vehicle. The inset photo is a black-and-white camera (CAM-B) image of a heat-flow instrument during dive 30 that is completely submerged in the bottom turbid layer. Lower panels show video images of ripple-like bedforms: (a, c) catenary shape at the slope regions and (b) linguoid shape at the basin floor (b). 
were ancient mass transport deposits more than $100 \mathrm{~m}$ beneath the seafloor.

\section{Methods}

We studied this area by three cruises in 2004, 2010, and 2011. All data were obtained by the Navigable Sampling System (NSS) of the Atmosphere and Ocean Research Institute of the University of Tokyo, which is a deep-sea remotely operated vehicle (ROV) designed to collect core samples with pinpoint accuracy. The pilot vehicle has four thrusters, a payload hook, and two downwardlooking video cameras: a color camera (CAM-A) hung from the pilot vehicle using an extension pipe and a black-and-white camera (CAM-B) mounted on the pilot vehicle. A pressure gauge and an acoustic altimeter provide water depth and distance above the seafloor with 0.1-m resolution. A sediment core sample was lost due to cable breakage during the 2004 survey (Ashi et al. 2012), and further core sampling was prohibited after the 2010 surveys to protect newly deployed submarine cables near the slope basin. Subbottom sedimentary structures were obtained during the 2011 cruise by a subbottom profiling (SBP) system (EdgeTech DW-106; EdgeTech, West Wareham, MA, USA) using a chirp signal generated with a frequency sweep from 1.5 to $4.5 \mathrm{kHz}$. The speed of the pilot vehicle during the SBP survey was about 0.9 knots. Profiles are shown converted from travel time to depth using a constant sonic velocity of $1,500 \mathrm{~m} / \mathrm{s}$.

\section{Dilute suspension layer and bottom turbid layer}

Ashi et al. (2012) reported seafloor disturbances due to earthquake shaking and their evolution between the cruises in 2004 and 2010. The September 2004 cruise started 2 weeks after the mainshock of the 2004 off-Kii Peninsula earthquakes. Twelve ROV dives (dives 29 to 36 and 40 to 43) were conducted near the epicenters (Figure 1). All dive observations on the prism slope noted a snow-like suspension of marine particles within 200 to $320 \mathrm{~m}$ of the seafloor (Ashi et al. 2012), but this dilute suspension layer (DSL) was not recognized in the forearc basin site (dives 30, 31, and 32). The DSL on the prism slope was ascribed to clouds of suspended sediment produced by mass movements at multiple locations during the earthquakes. Dives 40, 41, and 42 documented a localized layer of extremely high turbidity at the bottom of the slope basin (site NG2 hereafter) (Figure 2). The upper boundary of this high-turbidity layer was very clearly defined and exhibited a pseudoseafloor on video images (Ashi et al. 2012). This first cruise, therefore, revealed two types of turbid layers: a widespread DSL and a localized bottom turbid layer (BTL) at site NG2. The BTL was estimated to be at least 1.5-m thick from its complete burial of a pogo-type heatflow probe system (Figure 2).

During the 2010 cruise, two dives (dives 87 and 95) revisited the slope basin where previous dives (dives 36, 40, 41, and 42) observed both DSL and BTL in 2004 (Ashi et al. 2012). The transparency of the seawater was high without any indication of DSL and BTL.

\section{Results}

\section{Settlement of the BTL}

According to Ashi et al. (2012), the water depth at site NG2 changed from about $3,816.0 \mathrm{~m}$ in 2004 (surface to BTL) to about $3,818.4 \mathrm{~m}$ in 2010 (surface to bottom), which indicates a change of about $2.4 \mathrm{~m}$. To visually compare seawater turbidity, Ashi et al. (2012) combined data from dives 40 and 42 (in 2004) using the same combination of camera and lights, without consideration of tidal effects. In this study, we took account of tidal effects to improve the thickness estimate for the turbid layer. Relative to dives 40,41, and 42 (in 2004), dives 87 (in 2010) and 124 (in 2011) showed increases in water depth, but all dives showed depth variations within the dive periods (Figure 3). Discrepancies greater than $1 \mathrm{~m}$ were observed between the three 2004 dives, and water depth during dive 41 gradually increased with time (especially from $14: 00$ to $16: 00$ ) at the same location. Tidal changes during the dives, which are estimated using the ocean tidal prediction model NAO.99b (Matsumoto et al. 2000), reached a maximum of $1.6 \mathrm{~m}$ in the study area (Figure 4). After we subtracted tidal effects, the water depths of the upper boundary of the BTL after the 2004 earthquakes were about $3,817 \mathrm{~m}$ with small variations (Figure 3). There was no apparent systematic temporal variation from dive 40 to dive 42, which were more than 1 day apart. The seafloor depths 6 and 7 years after the earthquakes were measured to be around $3,820 \mathrm{~m}$. The corrected depth data show that the difference in water depths between the two survey periods was about $3 \mathrm{~m}$. In consideration of data scattering, it can be said that the water depth difference was more than $2.5 \mathrm{~m}$ at least. However, it is likely that the BTL was somewhat thicker than this estimation soon after the earthquakes because some sediment must have settled from the BTL and DSL by the time of the survey dives.

\section{Thickness of the BTL estimated by a heat-flow probe system}

Two dives in 2004 carried out measurements using a pogo-type heat-flow probe system (Figure 2). During dive 42 , at site NG2, the probe was completely buried in the BTL (Figures 2 and 5a). After the heat-flow measurements were completed, the probe system was winched out of the seafloor and the water depth was estimated 


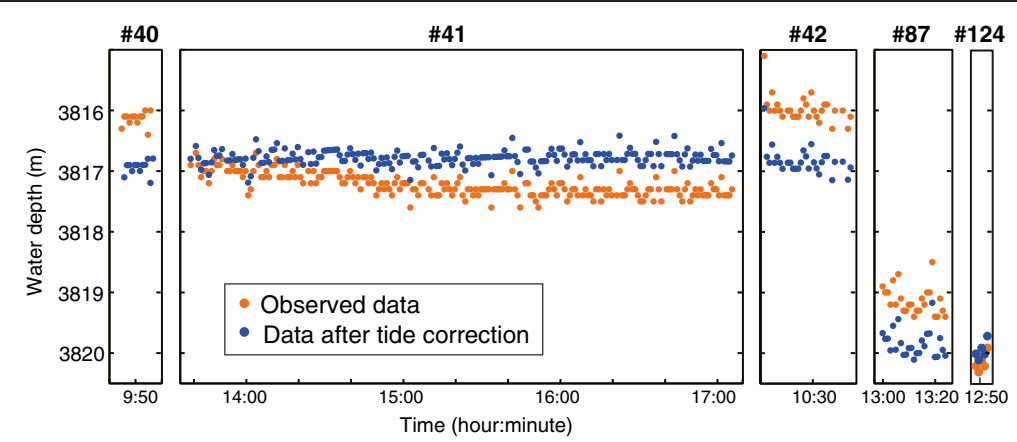

Figure 3 Water depth comparison during dives 40, 41, and 42 (2004) and 87 and 123 (2010, 2011). Orange dots indicate original values from Ashi et al. (2012), and blue dots show corrected data after removing tidal changes.

from the point at which the rope between the ROV and the probe system grew taut (Figure $5 \mathrm{~b}$ ); this was determined from the winch and depth records (Figure 6). The altitude of the ROV at that moment is defined as $H_{0}$. A sonic altimeter detected both a pseudo-seafloor at the upper boundary of the BTL and the top of the probe weight when the probe system emerged from the BTL (Figure 5c). Thus, the thickness of the BTL was calculated from the equation $L-H_{0},+Y$, where $L, H_{0}$, and $Y$ are the rope length between the ROV and the probe system, the ROV altitude when the rope grew taut, and the height of the probe weight $(0.6 \mathrm{~m})$, respectively.

The estimated thickness of the BTL was $2.6 \mathrm{~m}$ (Figure 6a). This value is consistent with the thickness estimate based

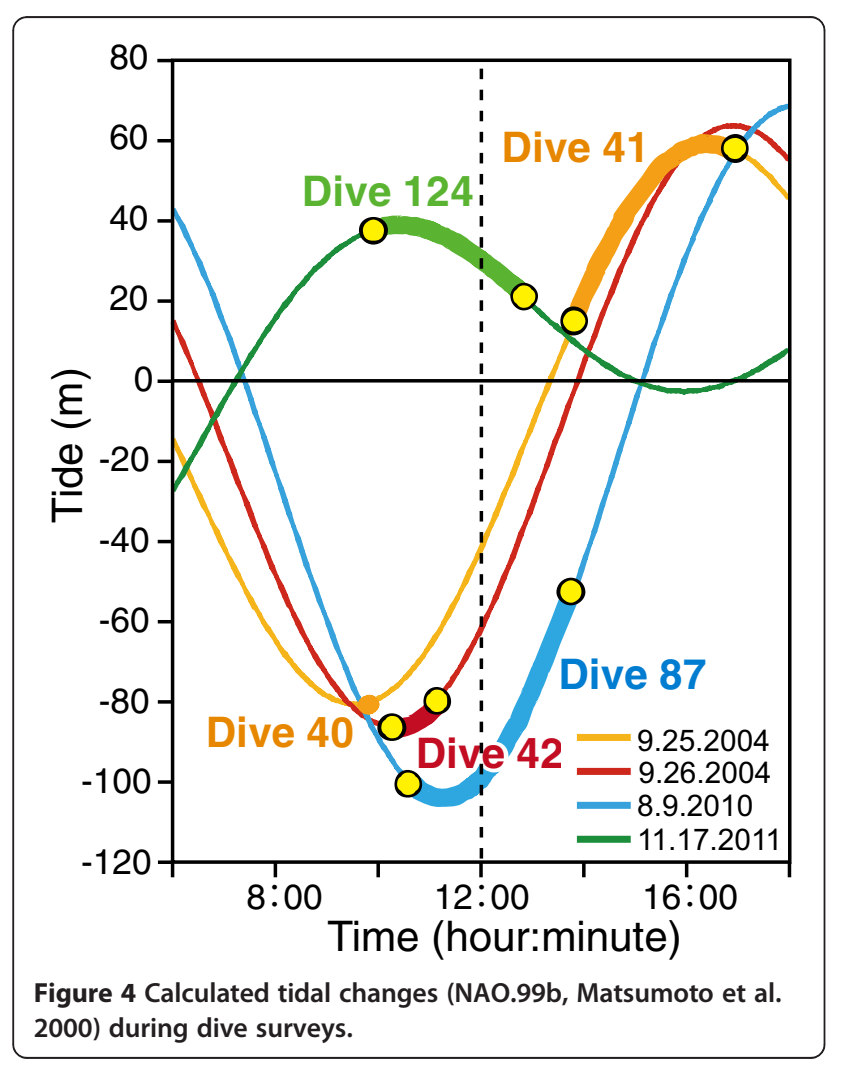

on comparison of the seafloor depth between 2004 and 2010 , although it is underestimated in the case of incomplete probe penetration. The instrumental record during dive 43 at a normal seafloor without BTL is shown in Figure 6b for comparison.

\section{Ripple-like bedforms}

Ripple-like bedforms parallel to depth contours were observed on the gentle northern slope of the basin at site NG2 during dives 36 and 95 (Ashi et al. 2012). Dive 124 (in 2011) ran from the eastern slope to the northwestern slope by way of the basin center and documented well-developed ripple-like bedforms in the slope regions (Figure 2). The directions of the ripple crests were NWSE on the eastern slope and NE-SW on the northwestern slope, roughly parallel to the depth contours. Shapes of these bedforms tended to be catenary in slope regions (Figure 2a,c) and linguoid or more complex on the flat basin floor at site NG2 (Figure 2b).

\section{Thick transparent layers in subbottom profiles}

The subbottom profiling survey was conducted during dive 124 in the terminal basin of site NG2 (Figures 2 and 7). The point of the deepest water depth in the SBP (Figure 7) was slightly landward of the basin center (Figure 2). The depocenter, as it appeared on the profile, was also located at this deepest point, which is suggestive of landward tilting by synsedimentary tectonics. Slight kink-folds by compressional deformation were observed at the landward margin of the basin. Reflections were recognized down to about $30 \mathrm{~m}$ below the seafloor (0.04 $\mathrm{s}$ in two-way travel time). The upper part of this sequence, which was 10- to 13-m thick, was characterized by a set of acoustically transparent layers, and the lower part consisted of well-stratified strata suggestive of thin alternations of sand and mud. Three transparent layers about 2-, 3-, and 5-m thick were widespread on the basin floor; these gradually thinned out toward the basin margin (Figure 7). Hummocky topography and a wedge-shaped acoustically 


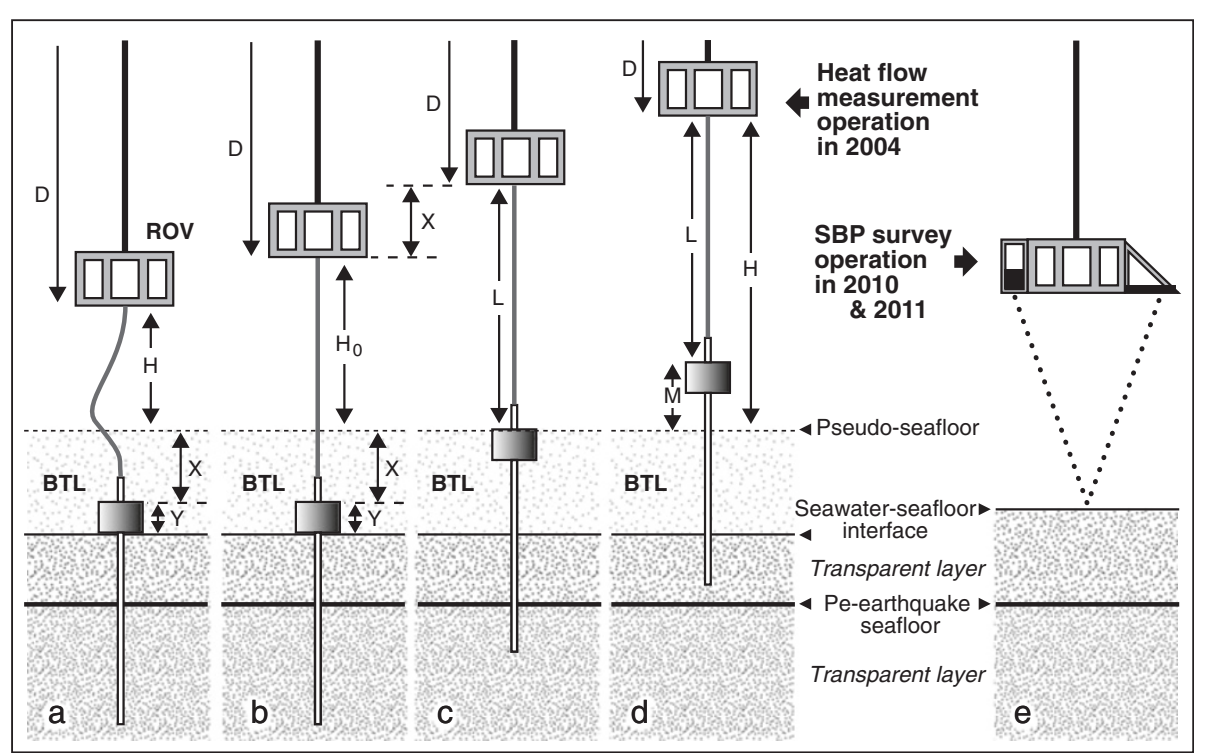

Figure 5 Schematic diagrams showing estimation of the BTL during a heat-flow measurement. (a to d) Operations soon after the 2004 earthquakes. (e) Operations in 2010 and 2011. ROV, remotely operated vehicle; SBP, subbottom profile.

chaotic body below it were observed at the northeastern part of the profile (Figure 7). This chaotic body seems to be stratigraphically correlated with the lowermost transparent layer. Three transparent layers thinner than $1 \mathrm{~m}$ appeared below the uppermost transparent layer around the depocenter (Figure 7a) and grew thinner toward the basin margin; these likely formed a condensed sequence with thicknesses smaller than the acoustic resolution of about $15 \mathrm{~cm}$ (Figure 7b). These thick transparent layers are suggestive of a sudden influx of a large amount of muddy material. In this respect, they resemble the transparent layer of the tsunami-induced sequence known as homogenite in the Mediterranean Sea (Polonia et al. 2013), although those deposits cover an area two orders of magnitude larger.

\section{Discussion}

We improved the thickness estimation of the BTL by considering regional tides. The result, which was greater than $2.5 \mathrm{~m}$, was similar to the previous estimate (greater than $2.4 \mathrm{~m}$ ) of Ashi et al. (2012) even though the regional tidal range was as large as $1.6 \mathrm{~m}$ (Figure 4). The two results are so consistent because three of the dives $(40,42,87)$ were conducted near low tide (Figure 4). The BTL thickness was independently estimated as $2.6 \mathrm{~m}$ from the submersion of a heat-flow probe system into the turbid layer. The consistency between these two estimates strongly indicates that a turbid layer more than $2.5-\mathrm{m}$ thick was present in the terminal basin soon after the earthquakes.
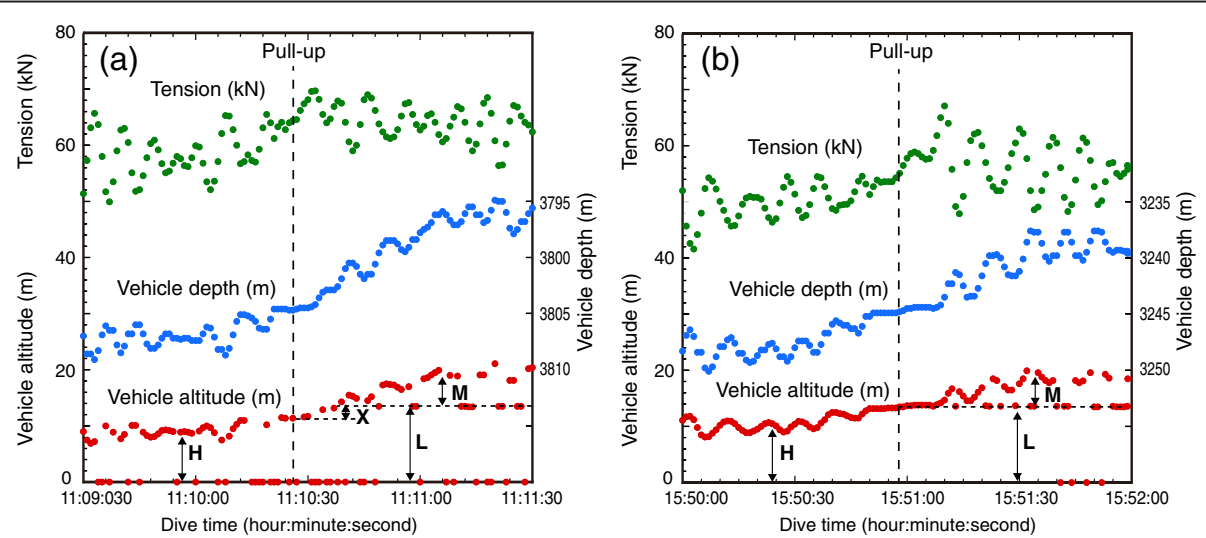

Figure 6 Time series of vehicle altitude, wire tension, and vehicle depth data during heat-flow measurements. (a) Seafloor with a BTL. The acoustic altimeter registers the weight of the heat-flow apparatus at extra distance X representing the thickness of the BTL. (b) Normal seafloor. The acoustic altimeter registers the weight of the heat-flow apparatus at the time that tension increases as the probe system is retrieved. 

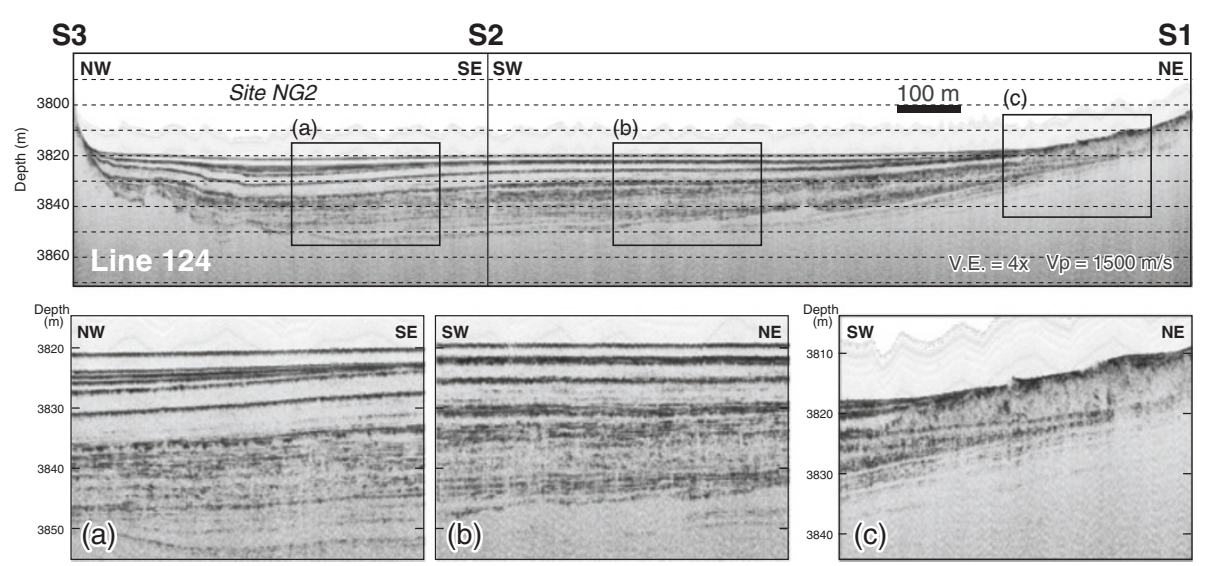

Figure 7 Subbottom profiles obtained during dive 124 in the terminal basin (location shown in Figure 2). Upper panel is a SBP profile between S1 and S3. Lower panels are close-up SBP profiles: (a) three thick transparent layers with three thin layers at site NG2, (b) widespread three thick transparent layers, and (c) hummocky topography and a wedge-shaped acoustically chaotic body below it.

The upper boundary of the BTL was very sharp and did not measurably change its depth during the two consecutive observation days in 2004. A BTL of the type we envision would have an anomalously low settling velocity because the suspended sediment concentration would be great enough that inter-particle interference would hinder settling (e.g., Nishida and Ito 2009). Therefore, the BTL probably consisted of fluid mud and formed a kind of lutocline (e.g., Ross and Mehta 1989). Judging from the thickness of the BTL, a considerable amount of sediment may have settled out before the first ROV observations 20 days after the mainshock.

We examined the possibility that surface sediment from the prism slope flowed episodically into the terminal basin, given that the basin is isolated from terrigenous sources and has no outflow pathway. The source area capable of supplying sediment to the basin by sediment gravity flow (white dotted line in Figure 1) has an area of about $85 \mathrm{~km}^{2}$. Although this value was estimated without consideration of sediment transport beyond barriers, it is assumed that a considerable amount of sediment could pass over topographic highs. Muck and Underwood (1990) indicated that the maximum run-up elevation of a turbidity current is approximately equal to 1.53 times the flow thickness, which was determined through field observations, theory, and laboratory models. The thicknesses of dilute suspension layers during the 2004 earthquakes were more than $200 \mathrm{~m}$ in the study area (Ashi et al. 2012). Moreover, the thickness of the similar turbidity anomalies observed during the 2011 Tohoku-oki earthquake increased with depth up to about 1,300 $\mathrm{m}$ above the seafloor (Noguchi et al. 2012). Although there is no evidence about how much the height barrier turbidity currents or suspension clouds were that passed beyond, the source area capable of supplying sediment to the basin is $688 \mathrm{~km}^{2}$ for the case of a 100-m-high barrier (white dashed line in Figure 1).
The volume of the uppermost transparent layer was estimated as follows. The margin of the basin is at 3,818-m water depth, and the area of the basin is about $2.0 \mathrm{~km}^{2}$. Thus, the sediment source area without or with consideration of the over barrier is about 42.5 or 344 times larger than the basin, respectively. The transparent layer is not of constant thickness but thins toward the basin margin (Figure 7), and hence, the estimated volume of the transparent layer was about $0.0024 \mathrm{~km}^{3}$. An even layer of surface sediment from the theoretical source area just 28.2- or 3.5$\mathrm{mm}$ thick could produce the transparent layer without or with consideration of the over barrier, respectively. Considering a typical porosity of $60 \%$ to $80 \%$, the source layer would likely be twice that of the thickness. Of course, the sediment source would be heterogeneous rather than a planar layer; nevertheless, it can be said that the uppermost transparent layer could have been deposited in a short period of time. Remobilization of thin sediment veneer by earthquake shaking was also reported from turbidity sensor monitoring and surface sediment sampling 1 month after the 2011 Tohoku-oki earthquake (Noguchi et al. 2012).

The ripple-like bedforms on the slope surrounding the basin are consistent with downslope gravity flows of sediment (Figure 2). Although such bedforms only indicate the paleocurrent directions during or after the fatal stage of the seismic event deposition, they can provide us with information about the paths of sediment supply to the terminal basin. The shapes of the ripple-like bedforms tend to have complex patterns on the flat basin floor, which are presumably due to the superimposition of flows of various directions and timing.

We suggest that the thick turbid layer and probably the transparent layers in the terminal basin developed by accumulation of fine-grained sediment derived from multiple directions. Widely observed clouds of suspended sediment soon after the 2004 earthquakes suggest that earthquake 
shaking caused sediment gravity flows to dump mud into the terminal basin and form thick acoustically transparent layers. The series of these transparent layers documented by subbottom surveys, then, is indicative of repeated events supplying muddy sediment during past seismic shaking. Stratigraphical continuity from the wedge-shaped chaotic body below the hummocky seabed relief to the lowermost transparent layer (Figure 7c) strongly suggests that a submarine landslide was a source for sediment remobilization. Many slump scars appeared in the detailed seafloor morphology of the upslope region Strasser et al. (2011); these are also candidates for the sediment sources.

\section{Conclusion}

The water layer of extremely high turbidity observed in a terminal basin on the prism slope soon after the 2004 off-Kii Peninsula earthquakes was studied by a high-resolution subbottom profiler. Comparing the seafloor depths from surveys in 2004 and 2010, the thickness of the BTL was estimated to be more than $2.5 \mathrm{~m}$. The BTL thickness was independently estimated to be $2.6 \mathrm{~m}$ by submersion of a heat-flow probe system in the turbid layer. The existence of this thick BTL suggests that a large amount of sediment may have settled out of suspension before the first dive 20 days after the mainshock. The subbottom profile across the terminal basin was characterized by a sequence of homogeneous transparent layers. We conclude that the thin veneer of sediment on the prism slope could be mobilized to flow into the basin by earthquake shaking and create the observed BTL. Accordingly, it can be said that a terminal basin on a prism slope can serve as an excellent earthquake recorder.

\section{Competing interests}

The authors declare that they have no competing interests.

\section{Authors' contributions \\ JA carried out the deep-tow subbottom survey, observed the seafloor, and drafted the manuscript. RS estimated the tidal effects on the thickness of the high turbid layer and mapped the ripple-like structures. $\mathrm{AO}$ and $\mathrm{KI}$ participated in the sedimentological interpretation. All authors read and approved the final manuscript.}

\section{Acknowledgements}

We thank the RN Kaiyo and the R/V Hakuho-maru captains, crewmembers, and technicians for their contributions to the success of the ROV surveys. Various support by Hidekazu Tokuyama, Katsura Kameo, and the shipboard scientists are highly appreciated. The authors are grateful to the editor, Masataka Kinoshita, for his helpful comments, and to Michael Strasser and the anonymous reviewer for providing many constructive suggestions, which have significantly improved our paper. This work was supported by a Grant-in-Aid for Scientific Research on Innovative Areas (No. 21107003) from MEXT of Japan.

\section{Author details}

${ }^{1}$ Atmosphere and Ocean Research Institute, The University of Tokyo, 5-1-5 Kashiwanoha, Kashiwa, Chiba 277-8564, Japan. ${ }^{2}$ Marine Works Japan Ltd, 3-54-1 Oppamahigashi, Yokosuka 237-0063, Japan. ${ }^{3}$ JSPS Research Fellow, Graduate School of Frontier Sciences, The University of Tokyo, 5-1-5 Kashiwanoha, Kashiwa, Chiba 277-8564, Japan. ${ }^{4}$ Geological Survey of Japan, AIST, 1-1-1 Higashi, Tsukuba, Ibaraki 305-8567, Japan.
Received: 21 February 2014 Accepted: 30 May 2014

Published: 12 June 2014

\section{References}

Ando M (1975) Source mechanisms and tectonic significance of historical earthquakes along the Nankai Trough, Japan. Tectonophysics 27:119-140, doi:10.1016/0040-1951(75)90102-X

Arai K, Naruse H, Miura R, Kawamura K, Hino R, Ito Y, Inazu D, Yokokawa M, Izumi N, Murayama M, Kasaya T (2013) Tsunami-generated turbidity current of the 2011 Tohoku-Oki earthquake. Geology 41:1195-1198, doi:10.1130/G34777.1

Ashi J, Lallemant S, Masago H (2007) NanTroSEIZE stage 1: NanTroSEIZE megasplay riser pilot. IODP Sci Prospectus 315:1-78, doi:10.2204/iodp.sp.315

Ashi J, Ikehara K, Kinoshita M, KY04-11, KH-10-3 Shipboard Scientists (2012) Settling of earthquake-induced turbidity on the accretionary prism slope of the central Nankai subduction zone. In: Yamada Y, Kawamura K, Ikehara K, Ogawa Y, Urgeles R, Mosher D, Chaytor J, Strasser M (eds) Submarine mass movements and their consequences, advances in natural and technological hazards research, 31st edn. Springer, Dordrecht, pp 561-571

Goldfinger C (2011) Submarine paleoseismology based on turbidite records. Ann Rev Mar Sci 3:35-66

Heezen BC, Ericson DB, Ewing M (1954) Further evidence for a turbidity current following the 1929 grand banks earthquake. Deep-Sea Res 1(4):193-202, doi:10.1016/0146-6313(54)90001-5

Ikehara K, Irino T, Usami K, Jenkins R, Omura A, Ashi J (2014) Possible submarine tsunami deposits on the outer shelf of Sendai Bay, Japan resulting from the 2011 earthquake and tsunami off the Pacific coast of Tohoku. Mar Geol 349:91-98

Itou M, Matsumura I, Noriki S (2000) A large flux of particulate matter in the deep Japan Trench observed just after the 1994 Sanriku-Oki earthquake. Deep-Sea Res Part I. Oceanogr Res 47:1987-1998, doi:10.1016/S0967-0637(00)00012-1

Kasaya T, Mitsuzawa K, Goto T, Sayanagi K, Araki E, Asakawa K, Iwase R, Mikada H, Nagao T (2009) Trial of multidisciplinary observation at an expandable submarine cabled station "off-Hatsushima Island Observatory" in Sagami Bay, Japan. Sensors 9:9241-9254, doi:10.3390/s91109241

Kinoshita M, Tobin H, Ashi J, Kimura G, Lallemant S, Screaton EJ, Curewitz D, Masago H, Moe KT, Expedition 314/315/316 scientists (2009) NanTroSEIZE stage 1: investigations of seismogenesis, Nankai Trough, Japan., Proc IODP 314/315/316. doi:10.2204/iodp.proc.314315316.123

Martin KM, Gulick S, Bangs NB, Moore GF, Ashi J, Park JO, Kuramoto S, Taira A (2010) Possible strain partitioning structure between the Kumano fore-arc basin and the slope of the Nankai trough accretionary prism. Geochem Geophys Geosyst 11:Q0AD02, doi:10.1029/2009GC002668

Matsumoto K, Takanezawa T, Ooe M (2000) Ocean tide models developed by assimilating TOPEX/POSEIDON altimeter data into hydrodynamical model: a global model and a regional model around Japan. J Oceanogr 56:567-581

Miyazaki SI, Heki K (2001) Crustal velocity field of southwest Japan: subduction and arc-arc collision. J Geophys Res 106:4305-4326, doi:10.1029/ 2000JB900312

Moore GF, Bangs NL, Taira A, Kuramoto S, Pangborn E, Tobin HJ (2007) Three-dimensional splay fault geometry and implications for tsunami generation. Science 318:1128-1131, doi:10.1126/science.1147195

Moore G, Kanagawa K, Strasser M, Dugan B, Maeda L, Toczko S (2014) IODP expedition 338: NanTroSEIZE stage 3: NanTroSEIZE plate boundary deep riser 2. Sci Drill 17:1-12, doi:10.5194/sd-17-1-2014

Muck MT, Underwood MB (1990) Upslope flow of turbidite currents: a comparison among field observations, theory, and laboratory models. Geology 18:54-57, doi:10.1130/0091-7613 (1992)0202.3.CO;2

Nishida N, Ito M (2009) Fluid mud: distinctive features and implications for genetic stratigraphy. J Geol Soc Japan 115:149-167, Japanese with English abstract

Noguchi T, Tanikawa W, Hirose T, Lin W, Kawaguchi S, Yoshida-Takashima Y, Honda M, Takai K, Kitazato H, Okamura K (2012) Dynamic process of turbidity generation triggered by the 2011 Tohoku-Oki earthquake. Geochem Geophys Geosyst 13:Q11003, doi:10.1029/2012GC004360

Park JO, Tsuru T, Kodaira S, Cummins PR, Kaneda Y (2002) Splay fault branching along the Nankai subduction zone. Science 297:1157-1160

Polonia A, Bonatti E, Camerlenghi A, Lucchi R, Panieri G, Gasperini L (2013) Mediterranean megaturbidite triggered by the AD 365 Crete earthquake and tsunami. Sci Rep 3:1285, doi:10.1038/srep01285

Ross MA, Mehta AJ (1989) On the mechanics of lutoclines and fluid mud. J Coastal Res 5:51-61 
Saito T, Satake K, Furumura T (2010) Tsunami waveform inversion including dispersive waves: the 2004 earthquake off Kii Peninsula, Japan. J Geophys Res 115:B06303, doi:10.1029/2009JB006884

Sakaguchi A, Kimura G, Strasser M, Screaton E, Curewitz D, Murayama M (2011) Episodic seafloor mud brecciation due to great subduction zone earthquakes. Geology 39:919-922, doi:10.1130/G32043

Sakai S, Yamada T, Shinohara M, Hagiwara H, Kanazawa T, Obana K, Kodaira S, Kaneda Y (2005) Urgent aftershock observation of the 2004 off the Kii Peninsula earthquake using ocean bottom seismometers. Earth Planets Space 57:363-368

Seeber L, Mueller C, Fujiwara T, Arai K, Soh W, Djajadihardja YS, Cormier MH (2007) Accretion, mass wasting, and partitioned strain over the 26 Dec 2004 Mw9.2 rupture offshore Aceh, northern Sumatra. Earth Planet Sci Lett 263:16-31, doi:10.1016/j.epsl.2007.07.057

Seno T, Stein S, Grippe AE (1993) A model for the motion of the Philippine Sea plate consistent with NUVEL-1 and geological data. J Geophys Res 98:17941-17948

Strasser M, Moore GF, Kimura G, Kopf AJ, Underwood MB, Guo J, Screaton E (2011) Slumping and mass transport deposition in the Nankai fore arc: evidence from IODP drilling and 3-D reflection seismic data. Geochem Geophys Geosyst 12:Q0AD13, doi:10.1029/2010gc003431

Strasser M, Henry P, Kanamatsu T, Moe KT, Moore GF (2012) Scientific drilling of mass-transport deposits in the Nankai accretionary wedge: first results from IODP Expedition 333. In: Yamada Y, Kawamura K, Ikehara K, Ogawa Y, Urgeles R, Mosher D, Chaytor J, Strasser M (eds) Submarine mass movements and their consequences, advances in natural and technological hazards research, 31 st edn. Springer, Dordrecht, pp 671-681

Sultan N, Cattaneo A, Sibuet J, Schneider J, Team SA (2009) Deep sea in situ excess pore pressure and sediment deformation off NW Sumatra and its relation with the December 26, 2004 great Sumatra-Andaman earthquake. Int J Earth Sci 98:823-837, doi:10.1007/s00531-008-0334-z

Takeuchi A, Shipboard Scientific Party of RN Yokosuka, Japan Sea Cruise (1998) Bottom response to a tsunami earthquake: submersible observations in the epicenter area of the 1993 earthquake off southwestern Hokkaido, Sea of Japan. J Geophys Res 103(B10):24109-24125, doi:10.1029/98JB00572

Thunell R, Tappa E, Varela R, Llano M, Astor Y, Muller-Karger F, Bohrer R (1999) Increased marine sediment suspension and fluxes following an earthquake. Nature 398:233-236

Tobin HJ, Kinoshita M (2006) NanTroSEIZE: the IODP Nankai Trough Seismogenic Zone Experiment. Sci Drill 2. doi:10.2204/iodp.sd.2.06.2006

Wolanski E, Chappell J, Ridd P, Vertessy R (1988) Fluidization of mud in estuaries. J Geophys Res 93:2351-2361

Yamada Y, Kawamura K, Ikehara K, Ogawa Y, Urgeles R, Mosher D, Chaytor J, Strasser M (2012) Submarine mass movements and their consequences. In: Yamada Y, Kawamura K, Ikehara K, Ogawa Y, Urgeles R, Mosher D, Chaytor J, Strasser M (eds) Submarine mass movements and their consequences, advances in natural and technological hazards research, 31st edn. Springer, Dordrecht, pp 1-12

doi:10.1186/1880-5981-66-51

Cite this article as: Ashi et al: Accumulation of an earthquake-induced extremely turbid layer in a terminal basin of the Nankai accretionary prism. Earth, Planets and Space 2014 66:51.

\section{Submit your manuscript to a SpringerOpen ${ }^{\circ}$ journal and benefit from:}

- Convenient online submission

- Rigorous peer review

- Immediate publication on acceptance

- Open access: articles freely available online

- High visibility within the field

- Retaining the copyright to your article

Submit your next manuscript at $\gg$ springeropen.com 